\title{
Introducing Doug Wade
}

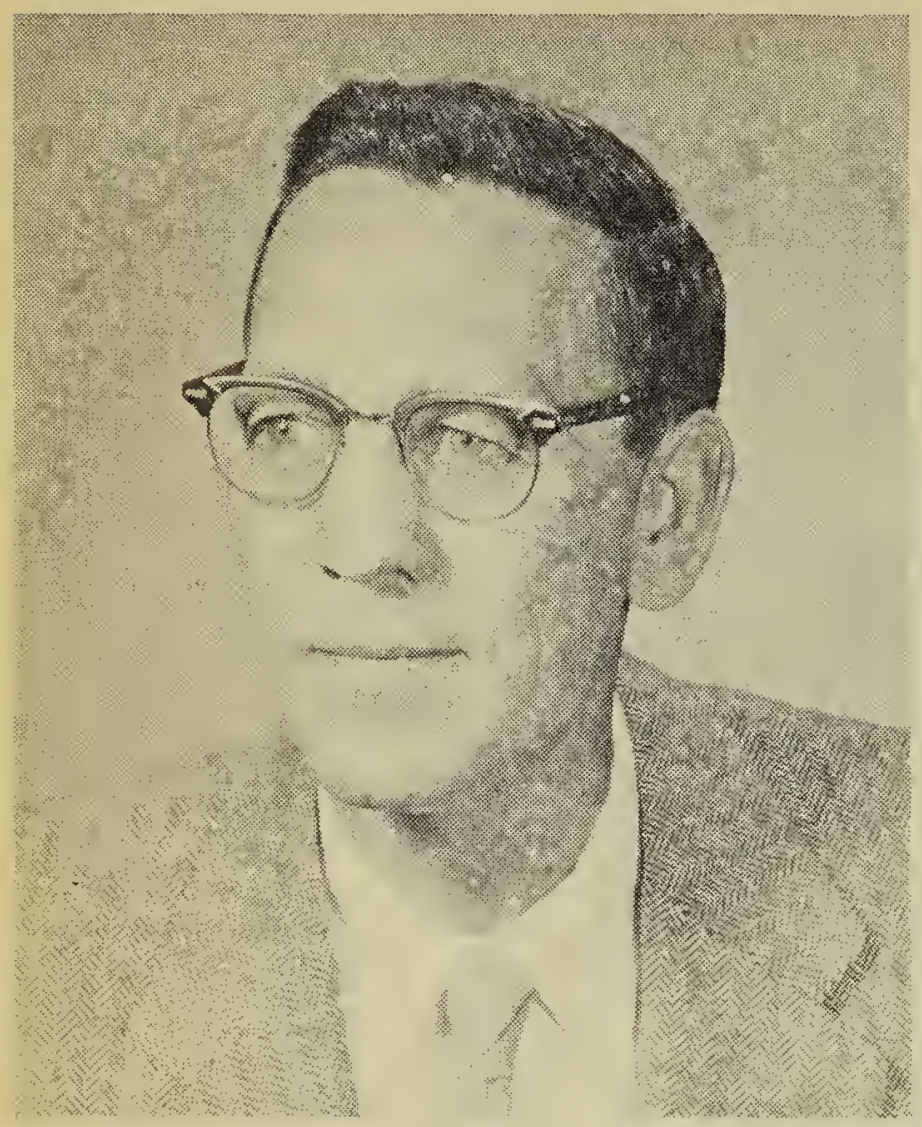

Sask. Govt. Photo

DOUGLAS WADE, recently appointed supervisor of Conservation Information Service, D.N.R.

On Friday May 13 the Wade family journeyed north from North Portal, Saskatchewan, to Regina. They drove through a heavy dust storm the entire distance. They knew that the dust told a story of land abuse in a country of low rainfall and demonstrated the great need for more vigorous and intensive land and water conservation programs.

Doug Wade, the senior member of the family, is now employed by the Saskatchewan Department of Natural Resources as supervisor of the Conservation Information Service. Previously he had served as naturalistin-residence at Dartmouth College in New Hampshire, director of the New Jersey State School of Conservation, fur researcher with the Pennsylvania Game Commission, education director for the South Carolina Wildlife Resources Commission, a teacher at the University of Missouri and Clemson College in South Carolina, and most recently, as editor of the Journal of Soil and Water Conservation with offices in Des Moines, Iowa.

Both Doug and Dot Wade attended the University of Wisconsin where
Doug received a master's degree in wildlife management under the famed Aldo Leopold. Mrs. Wade majored in landscaping and botany. Doug is originally from Wisconsin, and Dot from New Jersey. The Wades have two children. Lila, a daughter, is married and now residing in New Hampshire. Alan, aged thirteen, is busy becoming acquainted with Saskatchewan's rich natural history and fish life.

Doug served for five years as editor of the New Hampshire-Audubon Society Bulletin and for five years on the editorial board of the Carolina Bird Club. He has made a film of the "Peregrine Falcon on its Eyrie" (filmed largely in Vermont and New Hampshire), and visited over 180 eyries in eastern Nonth America. He also made a special tape-recording study of the American Woodcock on its peenting grounds.

Dot Wade has published a guide to spring flowers of the Hanover, New Hampshire area and maintains a herbarium of plants collected in many midwestern and northeastern states. Already she has started to collect and list plants of Saskatchewan and finds an entirely new and fascinating array of plants and habitats to explore, list, study and photograph.

Although Alan has not yet pulled in any "record-busting" fishes, he knows that there are many virgin lakes and streams awaiting exploration, especially in the northern half of the province, in spite of mud, dust and bugs.

The Wades have joined the Saskatchewan Natural History Society and the Regina Society. Doug, in his work with the Department of Natural. Resources, feels that the natural history societies have made many significant contributions to a better understanding of the wild plant and animal resources of the Province. $\mathrm{He}$ also feels that there are many more opportunities for natural history groups to make still greater contributions which can be shared by all who reside in the province.

The Saskatchewan Natural History Society welcomes the Wades to the Society. 